\title{
RESPONSE OF YIELD AND YIELD ATTRIBUTES OF SOME BREAD WHEAT VARIETIES TO IRRIGATION LEVELS AND SEEDING RATE UNDER OLD LAND CONDITIONS \\ Ramadan, A.R. ${ }^{*}$ and S. S. Awaad ${ }^{\star *}$ \\ ${ }^{*}$ Field Crop Res. Institute. ARC, Giza, Egypt. \\ ${ }^{* *}$ Field crop Res. Institute Control. Lab. for Des. And stat. Anal. Res.
}

\section{ABSTRACT}

Two field experiments were performed in the experimental Farm, at Zankalon, Water Requirements Research Station, El-Sharkia Governorate, Water Management and Irrigation Systems Research Institute, National Water Research Center (NWRC), Egypt during two successive seasons at 2005/2006 and 2006/2007 to study the response of yield and yield attributes of some bread wheat varieties i.e., (Sakha 93 , Giza 168 and Gimmeiza 9) to irrigation levels ( $100 \%$ of field capacity , $80 \%$ of field capacity and $60 \%$ of field capacity) and seeding rates ( 60,70 and 80 $\mathrm{Kg}$./feddan) under in old land conditions. The obtained results could be summarized as follows:

Increasing irrigation levels from $I_{3}$ ( $60 \%$ of field capacity) to $I_{1}(100 \%$ of field capacity) gives significant for plant height, number of grains/spike , number of spikes $/ \mathrm{m}^{2}, 1000$ grain weight, grain yield/feddan and straw yield/feddan with in significant differences between $I_{1}\left(100 \%\right.$ of field capacity) and $I_{2}(80 \%$ of field capacity). Increasing irrigation levels from $I_{3}\left(60 \%\right.$ of field capacity) to $I_{1}(100 \%$ of field capacity) was in significantly affect for spike length, number of spikelets/spike and spike grain weight.

The cultivar Giza 168 gave taller plants followed by Gimmeiza 9, while Sakha 93 had shorter plants. The cultivar Gimmeiza 9 gave the longest spikes and much number of spikelets and grains /spike and number of spikes $/ \mathrm{m}^{2}$ followed by Sakha 93 and Giza 168 cultivars Gimmeiza 9 and Sakha 93 cultivars. significantly surpassed Giza 168 for 1000-grain weight and grain yield/feddan. Meanwhile, Giza 168 significantly surpassed Sakha 93 and Gimmeiza 9 cultivars in straw yield/feddan. However significant was showing with increasing seeding rate for plant height, number of spikes $/ \mathrm{m}^{2}$, and grain and straw yields/feddan with no significant differences between 60 to $70 \mathrm{Kg}$. /feddan in one side and from 70 to $80 \mathrm{Kg}$. /feddan for both grain and straw yield /feddan. However, the increasing seeding rate from 60 to $80 \mathrm{Kg}$. /feddan significantly increased plant height and number of spikes $/ \mathrm{m}^{2}$. However, increasing seeding rates from 60 to $80 \mathrm{Kg}$./feddan decreased significantly, number of spikelets/spike, number of grains /spike and 1000-grain weight with no significant difference between 60 to $70 \mathrm{Kg}$./feddan. Raising seeding rates from 60 to 70 or $80 \mathrm{Kg}$./feddan did not significantly affect spike grain weight.

Grain yield (ardab/feddan) was positively and significantly correlated with each of plant height $\left(0.598919^{*}\right)$ and number of spikes $/ \mathrm{m}^{2}\left(0.679488^{*}\right)$. While the relation was positive and insignificant with each of spike length $(0.212270)$, number of spikelets/spike $(0.448344)$, number of grains/spike $(0.268315)$ spike grain weight (0.539816),1000-grain weight(0.457077) and straw yield/feddan (0.331902).

Results of interactions between irrigation levels and varieties, between irrigation levels and seeding rates and between seeding rates and varieties recommended that Gimmeiza 9 cultivar. should be sown at irrigation levels $I_{2}$ ( $80 \%$ Of field capacity ) and at seeding rates of $80 \mathrm{Kg}$./feddan. While Giza 168 cultivar. should be sown at irrigation levels $\mathrm{I}_{2}(80 \%$ of field capacity) and at seeding rates of 70 $\mathrm{Kg} . /$ feddan. However, Sakha 93 cultivar. should be sown at irrigation levels $\mathrm{I}_{1}(100 \%$ of field capacity) and at seeding rates of $70 \mathrm{Kg}$. /feddan. 


\section{INTRODUCTION}

Wheat is considered the first leading cereal crop in the world. Increasing wheat yield per unit area had a national interest. In Egypt, the local production is not sufficient to meet the exponential increase in population. Therefore, any attempts for raising wheat production are considered a matter of utmost importance. Such attempts could be achieved either by increasing area cultivated with wheat or by raising the yield per feddan. Irrigating for maximum crop yield and quality is often a matter of correct timing as well as correct amounts. It is necessary to have a good understanding of the crop water needs and timing, as well as knowledge of the physical and chemical soil characteristics such as available water holding capacity and infiltration rate.

To obtain maximum yields from any crop, plants should retain relatively free of water stress. The relationships between crop yields of wheat and water use are complicated. Wheat yield may depend on when water is applied or on the amount. Information on optimal scheduling of limited amounts of water to maximize yields of high quality crops is essential if irrigation water is to be used most efficiently (Al-Kaisi et al., 1997).; English and Nakamura, 1989; Ghahraman and Sepaskhah, 1997). Husman et al. (2000) cleared that irrigation at $50 \%$ soil water depletion or less is optimal for wheat grain yield. Aly et al. (2007) reported that, the highest yield of wheat was obtained with the low water deficit. Ouda (2006) showed that the yield of both wheat varieties were reduced under deducting $20 \%$ of irrigation water by 8.62 and $8.76 \%$ for Sakha 93 and Giza 168, respectively.

Many researchers cleared that wheat cultivars differ in their ability to yield and yield attributes. They reported that the varietal differences might be attributed to genetical constitution as well as the range of cultivar response. Blum and Punel, (1990) tested 12 spring wheat cultivars. and reported significant differences among in number of spikes $/ \mathrm{m}^{2}$ and grain weight/spike. El-Banna and Aly, (1993) reported that Sakha 8, Sakha 61, Giza 164 and Gimmeiza 10 cultivars. attained higher number of spikes $/ \mathrm{m}^{2}$ and grain yield/fed. Compared with Giza 157, Giza 163, Sakha 69, Sakha 92. Darwish, (1994) found that sakha 69 wheat. Surpassed Giza 157 in number of spikes $/ \mathrm{m}^{2}$, grain weight /spike and grain yield/fed. Khater et al, (1997) found that Gimmeiza 10 surpassed Sakha 8, Sakha 69, Giza 163 and Giza 164 wheat in number of spikes $/ \mathrm{m}^{2}$; grain weight/spike and grain yield/fed. ElBanna, (1999) reported that Gimmieza 10 had higher number of spikes $/ \mathrm{m}^{2}$ compared with the other wheat. tested (Sids 6, Giza 163 and Sakha 8) and less number of grains/spike and grain yield/fed. Ramadan, (2003) revealed that Giza 167 had higher number of spikes $/ \mathrm{m}^{2}$ meanwhile, Sids 2 gave the highest grain number/spike and grain yield/fed., Sakha 69 produced heaviest grain weight/spike. However, the heaviest 1000-grain was observed with Giza 164.

Most of the previous studies have shown different effects for seeding rate on yield and yield attributes of wheat. El-Bana and Basha, 1994; Abdalla and Bassiouny, 1994; Abo Warda 1997; El-Karamity, 1998; and Ramadan, 
2003, reported increases in plant height, number of spikes/ unit area, grain and straw yields with increasing seeding rates, while number of grains /spike and 1000-grain weight were decreased. Spike length, number of spikelets and grains/spike in addition to 1000-grain weight were decreased but plant height, number of spikes /unit area, grain and straw yields were increased with increasing seeding rates from (20 t0 $60 \mathrm{Kg}$./fed. (Salem et al., 1990); 25 to $75 \mathrm{Kg}$./fed. (Mahmoud, 1988), 45 to $75 \mathrm{Kg}$. /fed. (Bassal, 1997), ElKaramity,1998) and from 50 to $90 \mathrm{Kg} . / \mathrm{fed}$ (El-Banna, 2000). However, ElBanna, (2000) did not find significant effect on 1000-grain weight with the increasing in seeding rate from 70 to $90 \mathrm{Kg}$./fed. On the other hand, Hussein, (2005) reported that maximum grain yield was obtained with a seeding rate of $70 \mathrm{~kg} . / \mathrm{fed}$.

This study was amied to investigate the response of yield and yield components of three local wheat cultivars to Irrigation levels and seeding rates

\section{MATERIALS AND METHODS}

\section{1- Description of the studied materials and experimental logout}

Two field experiments were conducted during two winter successive seasons of 2004/2005 and 2005/2006 at Zankalon, Water Requirements Research Station, El-Sharkia Governorate, Water Management and Irrigation Systems Research Institute, National Water Research Center (NWRC).

In each experiment, 27 treatments which were the combination of three Irrigation levels, three wheat cultivars and three seeding rates are tested in a strip split plot design with three replicates. Irrigation levels were assigned to vertical plots, wheat varieties occupied the horizontal plots, whereas seeding rates were devoted to sub plots in horizontal. The preceding crops were rice and maize in the two seasons, respectively.

The agricultural method was drill on ridges $120 \mathrm{~cm}$; width; length was $10 \mathrm{~m}$ every ridge contents 6 rows $; 20 \mathrm{~cm}$ apart between hills $10 \mathrm{~cm}$. The plot size was $12 \mathrm{~m}^{2}$. The irrigations was applied after sowing for optimum water implations.

Phosphorus and potassium fertilizer levels were applied in one dose before sowing in form of calcium super phosphate $\left(15.5 \% \mathrm{P}_{2} \mathrm{O} 5\right)$ and potassium sulphate $\left(50 \% \quad \mathrm{~K}_{2} \mathrm{O}\right)$. Calcium superphosphate and potassium sulphate were added by rates of 100 and $50 \mathrm{Kg}$. /feddan, respectively. Seventy $\mathrm{Kg} . \mathrm{N} / \mathrm{feddan}$ was added in three equal doses at sowing, tillering and booting stage in the form of Urea $(46.5 \% \mathrm{~N})$.

This site is located at 30-35 N Latitude and 30-57 E Longitude with an elevation of East Nile Delta region. Soil of experimental site was clay in texture. Soil samples were collected to determine some soil physical and chemical properties of the experimental site. The average values of these measurements at different soil depths down to $60 \mathrm{~cm}$ are presented in Table (1). 
Table (1): Some soil physical and chemical properties of the experimental site

\begin{tabular}{|c|c|c|c|c|c|c|c|c|c|c|}
\hline $\begin{array}{l}\text { Depth } \\
\text { (cm) }\end{array}$ & $\begin{array}{c}\text { Sand } \\
\%\end{array}$ & $\begin{array}{l}\text { Silt } \\
\%\end{array}$ & $\begin{array}{c}\text { Clay } \\
\%\end{array}$ & texture & $\begin{array}{c}\text { Bulk } \\
\text { density } \\
\left(\mathrm{q} / \mathrm{cm}^{3}\right)\end{array}$ & \begin{tabular}{|c|} 
Field \\
capacity \\
$(\%)$
\end{tabular} & $\begin{array}{l}\text { Wilting } \\
\text { point } \\
\text { (\%) }\end{array}$ & $\begin{array}{l}\text { Available } \\
\text { water (\%) }\end{array}$ & $\begin{array}{c}\text { E.C } \\
\text { dsm }^{-1}\end{array}$ & $\mathrm{pH}$ \\
\hline $0-15$ & 25.80 & 28.90 & 43.51 & \multirow{5}{*}{ Clay } & 1.25 & 43.51 & 23.55 & 19.96 & 1.40 & 8.10 \\
\hline $15-30$ & 25.12 & 30.10 & 42.50 & & 1.27 & 40.50 & 21.06 & 19.44 & 1.22 & 8.00 \\
\hline $30-45$ & 26.90 & 31.50 & 40.50 & & 1.35 & 37.12 & 17.59 & 19.53 & 1.25 & 8.01 \\
\hline $45-60$ & 29.78 & 31.50 & 37.12 & & 1.40 & 36.25 & 16.62 & 19.63 & 1.05 & 8.02 \\
\hline Average & 26.90 & 30.50 & 40.91 & & 1.32 & 39.34 & 19.70 & 19.69 & 1.23 & 8.03 \\
\hline
\end{tabular}

\section{II- studied treatments}

The treatments were as follows:

1- Irrigation levels (I):

Irrigation water was applied to refill the soil profile $(60 \mathrm{~cm}$ depth) to the

Following levels:

a- $100 \%$ of field capacity $\left(\begin{array}{ll}I_{1} \\ l_{1}\end{array}\right.$

b- $80 \%$ of field capacity $\left(\mathrm{I}_{2}\right)$

c- $60 \%$ of field capacity $\left(\mathrm{I}_{3}\right)$

2- Wheat cultivars ( C ) :
a- Sakha 93
$\left(\mathrm{C}_{1}\right)$
b- Giza 168
c- Gimmeiza 9

3- Seeding rates $(\mathrm{S})$ :
a- $60 \mathrm{~kg}$. /feddan
$\mathrm{b}-70 \mathrm{~kg}$. /feddan
c - $80 \mathrm{~kg}$. /feddan

\section{C- Collected data}

At harvest, the third and the fourth ridge by area of $4.2 \mathrm{~m}^{2}$ were taken from each sub-sub plot to record, number of spikes $/ \mathrm{m}^{2}, 1000$ grain, grain yield /feddan, biological yield /feddan. Twenty seedlings from (second ridge) from each sub-sub plot were labeled at seedling stage for record plant height. In the meantime, 10 spikes were randomly taken to study, number of spikelets, number of grains/spike and grain weight/spike.

\section{D- Statistical analysis}

Fisher technique (Fisher's 1960) for comparison between means. Duncan multiple range tests were applied (Duncan, 1955). In interaction Tables, capital and small letters were used to compare both rows and columns averages, respectively. The combined data of yield attributes and characters related to quality with yield were subjected to simple correlation coefficients calculated according to Sendecor and Cochran (1967).

\section{RESULTS AND DISCUSSION}

\section{A- Effect of Irrigation levels:}

Data presented in Tables (2),(3) and (4) showed the effect of irrigation levels on yield and yield attributes of wheat in the two seasons and their combined analysis. Irrigation levels had significant effects in both seasons and their combined analysis on plant height, number of grains/spike, number 
of spikes $/ \mathrm{m}^{2}, 1000$ grain weight, grain yield/feddan and straw yield/feddan. These characters were increased with increasing irrigation levels from $I_{3}$ ( $60 \%$ of field capacity) to $I_{1}(100 \%$ of field capacity) with no significant differences between $I_{1}$ ( $100 \%$ of field capacity) and $I_{2}$ ( $80 \%$ of field capacity). The relative increase (combined data) due to increasing irrigation levels from $I_{3}$ to $I_{1}$ were $5.16,5.63,3.01,10.19,15.22$ and $23.05 \%$ in plant height , number of grains/spike, number of spikes $/ \mathrm{m}^{2}, 1000$-grain weight, grain yield/feddan and straw yield/ feddan, respectively.

The decreases in yield and yield attributes due to wheat irrigate at 13 ( $60 \%$ of field capacity) may be due to changes patterns of plant growth and development (Ouda, 2006) , disturbance metabolites transportation to the grains (Kramer and Boyer, 1995), reduced the number of reproductive tillers which limit their contribution to grain yield (Mosaad et al 1995) and caused pollen sterility (Saini et al 1984)

Results in tables (2) and (3) indicated that increasing irrigation levels from $I_{3}\left(60 \%\right.$ of field capacity) to $l_{1}$ ( $100 \%$ of field capacity) did not significantly affect spike length in both seasons and their combined analysis, number of spikelets/spike in the first season and combined analysis and spike grain weight in the first season. Combined data revealed that, maximum average of spike length $(9.56 \mathrm{~cm})$, number of spikelets/spike (19.32) and spike grain weight $(2.68 \mathrm{gm})$ were recorded when irrigation level was $l_{1}(100 \%$ of field capacity), while minimum average of spike length (8.23 $\mathrm{cm})$, number of spikelets/spike (18.11) and spike grain weight $(2.30 \mathrm{gm})$ were recorded when irrigation level was $I_{3}(60 \%$ of field capacity).

These results are in agreement with those obtained by (Mosaad et al. 1995) Husman et al (2000), Ouda (2006), Aly et al. (2007) and Kramer and Boyer (1995) who, reported that low soil moisture conditions caused losses of tissue water, which inhibit cell division and enlargement and reduced number of reproductive tillers and limit their contribution to grain yield.

\section{B- Varieties effect}

Results in Tables (2), (3) and (4) indicated that wheat varieties exhibited significant differences for both grain and straw yields, as well as, all studied yield attributes except spike length and number of grains/spike for both seasons and their combined, number of spikelets/spike in the first season and spike grain weight in the first and second seasons.

The combined analysis data in Table (2) revealed that, Giza 168 and Gimmeiza9 varieties significantly surpassed sakha 93 in plant height. Giza 168 gave taller plants $(98.88 \mathrm{~cm})$ followed by Gimmeiza $9(96.89 \mathrm{~cm})$, while Sakha 93 had shorter plants $(94.42 \mathrm{~cm})$. Moreover, it has been found herein that, Gimmeiza 9 had the longest spike, while Sakha 93 and Giza 168 gave the shortest ones. Data also showed that Gimmeiza 9 CV. loaded with much number of spikelets/spike (19.55) followed by Sakha 93 (18.73), while Giza 168 had the lowest number of spikelets/spike (17.61).

The average of both seasons data in Table (3) demonstrate that, Gimmeiza 9 cultivar produce highest values of number of grains /spike and spike grain weight followed by Sakha 93 and Giza 168. Furthermore, these results conclude that Gimmeiza 9. was of a high potentiAlyty to bearing 
number of spikes $/ \mathrm{m}^{2}$ (427.78) followed by Giza 168. (411.33) and Sakha93. (396.22), respectively.

Combined data given in Table (4) showed significant differences among wheat varieties in each of 1000-grain weight, grain and straw yield/feddan. It is clear from Table (4) that both Gimmeiza 9 and Sakha 93 significantly surpassed Giza 168 cultivar in 1000-grain weight and grain yield/feddan. Meanwhile, Giza 168 variety significantly surpassed Sakha 93 and Gimmeiza 9 cultivars in straw yield/feddan.

It could be concluded that varietal differences may be due to genetical differences between cultivars concerning partition of dry matter, where wheat varieties differed carbon equivalent, yield energy per plant and per feddan (Abd El-Gawad et al, 1987). The results of varietal differences in yield and yield attributes in this study are in agreement with those obtained by El-Banna and Aly, (1993) Darwish, (1994) Khater et al,(1997), El-Banna, (1999) and Ramadan, (2003) .

\section{C- Effect of seeding rates}

Data presented in Tables (2) , (3) and Table (4) show the effect of seeding rates on yield and yield attributes of wheat in the two seasons and their combined analysis. Seeding rates had significant effects in both seasons and their combined analysis on plant height, number of spikes $/ \mathrm{m}^{2}$, and grain and straw yields/feddan. The number of spikelets/spike and 1000grain weight. These characters were increased with increasing seeding rate from 60 to $80 \mathrm{Kg}$./feddan with no significant differences between 60 to 70 $\mathrm{Kg}$./feddan in one side and from 70 to $80 \mathrm{Kg}$./feddan in the other side for both grain yield /feddan and straw yield/feddan. However, the increase in plant height and number of spikes $/ \mathrm{m}^{2}$ was gradually due to raising seeding rate from 60 to 70 and $80 \mathrm{Kg}$. /feddan. The increase in plant height in dense sowing may be attributed to the reduction in light intensity within plant canopy, which enhance IAA synthesis and hence, increased cell. The increase in number of spikes $/ \mathrm{m}^{2}$ is mainly due to the increase of plant number per unit area (El-Karamity, 1998). The relative increase due to raising seeding rate from 60 to $80 \mathrm{Kg}$. /feddan was 11.17 and $16.15 \%$ in plant height and number of spikes/m2, respectively. (Combined data)

As shown in Tables (2) and (3) , increasing seeding rates from 60 to $80 \mathrm{Kg}$./feddan decreased significantly, number of spikelets/spike, number of grain /spike and 1000-grain weight with no significant differences between 60 to $70 \mathrm{Kg}$./feddan (combined data). On the other hand, raising seeding rates from 60 to 70 or $80 \mathrm{Kg}$. /feddan did not significantly affect spike grain weight in both seasons and their combined analysis.

In the combined data, the relative decreases due to raising seeding rate from 60 to $80 \mathrm{Kg}$./feddan in number of spikelets/spike (Table 2), number of grains / spike (Table 3) and 1000 grain weight (Table 4) were 14.25, 4.80 and $5.74 \%$, respectively. These results showed that dense sowing led to a severe competition among plants for nutrients, water supply and light. So, crowded plants become longer with lower tillering than those of thin sowing. Hence, a reduction in photosynthesis for dense plants could be expected which would be reflected on spike elongation and development as expressed in number of spikelets and grains per spike. 
J. Agric. Sci. Mansoura Univ., 33 (7), July, 2008

2 
Ramadan, A.R. and S. S. Awaad

3 
J. Agric. Sci. Mansoura Univ., 33 (7), July, 2008

4

4725 
As shown in the combined data (Table 4) grain and straw yield / feddan obtained with seeding rate $80 \mathrm{Kg} /$ feddan out yielded. With no significant differences between 70 and $80 \mathrm{Kg}$./feddan. The relative increases in grain and straw yields/feddan due to raising seeding rate from 60 to 80 $\mathrm{Kg}$./feddan were 13.17 and $18.10 \%$. The increase in grain yield due to dense sowing may be attributed to increase in number of spikes $/ \mathrm{m}^{2}$. The increase in straw yield is mainly due to the increase in number of plants per unit area coupled with plant height. These results are in agreement with those obtained by Abdalla and Bassiouny (1994), Abo warda (1997) ElKaramity (1998), Ramadan (2003), (El-Bana, 2000) and Hussein, (2005).

\section{D- Interaction effect:}

\section{D.1. Number of spikes $/ \mathrm{m}^{2}$ :}

Data presented in Table (3-a) and graphically illustrated in Fig. (1) Revealed that number of spikes $/ \mathrm{m}^{2}$ of wheat in the combined analysis was significantly affected by the interaction between irrigation levels and varieties. Results indicates that number of spikes $/ \mathrm{m}^{2}$ for the three tested was significantly increased with increasing irrigation levels. At different irrigation levels Gimmeiza 9 cultivar gave highest number of spikes $/ \mathrm{m}^{2}$ followed by Gimmeiza 9, Giza 168 and Sakha 93 respectively Gimmeiza 9 and Sakha 93 produced the height number of spikes $/ \mathrm{m}^{2}$ at Irrigation level $\mathrm{I}_{2}(80 \%$ of field capacity) with no significant difference between $I_{2}$ and $I_{1}$. However, Giza 168 cultivar produced the highest number of spikes $/ \mathrm{m}^{2}$ at $\mathrm{I}_{1}(100 \%$ of field capacity).

Table (3-a): Number of spikes $/ \mathrm{m}^{2}$ as affected by the interaction between Irrigation levels (I) and Varieties (V) interaction (combined data)

\begin{tabular}{|c|c|c|c|}
\hline \multirow[b]{2}{*}{ Verities(V) } & \multicolumn{3}{|c|}{ Irrigation Levels(I) } \\
\hline & FC 100\% & FC 80\% & FC $60 \%$ \\
\hline \multirow[b]{2}{*}{ Sakha 93} & $\mathrm{~A}$ & $\mathrm{~A}$ & $\mathrm{~B}$ \\
\hline & $398.32 \mathrm{c}$ & $397.52 \mathrm{c}$ & $392.82 \mathrm{c}$ \\
\hline \multirow[b]{2}{*}{ Giza 168} & $\mathrm{~A}$ & $\mathrm{~B}$ & $\mathrm{C}$ \\
\hline & $419.23 \mathrm{~b}$ & $413.51 \mathrm{~b}$ & $401.25 \mathrm{~b}$ \\
\hline \multirow[b]{2}{*}{ Gimmeiza 9} & A & A & B \\
\hline & $433.78 \mathrm{a}$ & $428.96 \mathrm{a}$ & $420.60 \mathrm{a}$ \\
\hline
\end{tabular}

Data given in Table (3-b) and graphically illustrated in Fig. (2) Cleared that number of spikes $/ \mathrm{m}^{2}$ of wheat in the combined analysis was significantly affected by the interaction between irrigation levels and seeding rates . Results showed that number of spikes $/ \mathrm{m}^{2}$ was significantly increased with increasing irrigation levels under different seeding rates. Plants sown at $80 \mathrm{Kg}$./feddan and irrigated at level $\mathrm{I}_{1} \quad(100 \%$ of field capacity) produced Highest number of spikes $/ \mathrm{m}^{2}$. While the lowest number of spikes $/ \mathrm{m}^{2}$ was found under irrigation levels $I_{3}(60 \%$ of field capacity) at different seeding rates.

Results in Table (3-c) and graphically illustrated in Fig. (3) Showed that number of spikes $/ \mathrm{m}^{2}$ of wheat in the combined analysis was significantly affected by the interaction between varieties and seeding rates. 
J. Agric. Sci. Mansoura Univ., 33 (7), July, 2008

F1-2-3 
Results cleared that number of spikes $/ \mathrm{m}^{2}$ for the three tested was significantly increased with increasing seeding rates. Gimmeiza 9 gave highest number of spikes $/ \mathrm{m}^{2}(485.82)$ at seeding rate of $80 \mathrm{Kg}$. /fed. While Sakha 93 gave the lowest one (374.07) at seeding rate of $60 \mathrm{Kg}$. /feddan.

Table (3-b): Number of spikes $/ \mathrm{m}^{2}$ as affected by the interaction between Irrigation levels (I) and seeding rates (S) interaction (combined data)

\begin{tabular}{|c|c|c|c|}
\hline \multirow[b]{2}{*}{ Seeding rates(S) } & \multicolumn{3}{|c|}{ Irrigation Levels(I) } \\
\hline & FC 100\% & FC $80 \%$ & FC 60\% \\
\hline \multirow[b]{2}{*}{$60 \mathrm{Kg} . / \mathrm{fed}$} & A & $A$ & $\mathrm{~B}$ \\
\hline & $387.54 \mathrm{c}$ & $385.23 \mathrm{c}$ & $376.23 \mathrm{c}$ \\
\hline \multirow[b]{2}{*}{$70 \mathrm{Kg} . / \mathrm{fed}$} & A & $\mathrm{A}$ & $\mathrm{B}$ \\
\hline & $414.65 \mathrm{~b}$ & $410.64 \mathrm{~b}$ & $397.03 \mathrm{~b}$ \\
\hline \multirow[b]{2}{*}{$80 \mathrm{~kg} . / \mathrm{fed}}$. & A & $A B$ & $\mathrm{~B}$ \\
\hline & $449.14 \mathrm{a}$ & $444.12 \mathrm{a}$ & $441.41 \mathrm{a}$ \\
\hline
\end{tabular}

Table (3-c): Number of spikes $/ \mathrm{m}^{2}$ as affected by the interaction between Varieties (V) and seeding rates (S) interaction (combined data)

\begin{tabular}{|c|c|c|c|}
\hline \multirow{2}{*}{$\begin{array}{l}\text { Seeding } \\
\text { rates(S) }\end{array}$} & \multicolumn{3}{|c|}{ Varieties $(\mathrm{V})$} \\
\hline & Sakha 93 & Giza 168 & Gimmeiza 9 \\
\hline $60 \mathrm{Kg} . / \mathrm{fed}$ & $\frac{B}{374.07 c}$ & $\frac{A}{388.54 \mathrm{C}}$ & $\frac{A}{386.39 \mathrm{C}}$ \\
\hline $70 \mathrm{Kg} . / \mathrm{fed}$. & $\begin{array}{c}\mathrm{B} \\
402.33 \mathrm{~b}\end{array}$ & $\begin{array}{c}A \\
408.86 b\end{array}$ & $\begin{array}{c}A \\
411.13 \mathrm{~b}\end{array}$ \\
\hline $80 \mathrm{~kg} . / \mathrm{fed}$. & $\frac{C}{412.26 \mathrm{a}}$ & $\frac{B}{436.59 a}$ & $\frac{A}{485.82 \mathrm{a}}$ \\
\hline
\end{tabular}

\section{D.2. Thousand grain weight:}

Data given in Table (4-a) and graphically illustrated in Fig. (4) Cleared that 1000-grain weight in the combined analysis was significantly affected by the interaction between irrigation levels and varieties. Results showed that 1000- grain weight for the three cultivars tested were significantly increased with increasing irrigation levels. At different irrigation levels Gimmeiza 9 cultivar gave heaviest grains followed by Sakha 93 and Giza 168 respectively. Giza 168 and Sakha 93 produced the heaviest grains at irrigation level $I_{1}(100 \%$ of field capacity). While, Gimmeiza 9 cultivar produced the heaviest one at $l_{1}(100 \%$ of field capacity) with no significant difference with $\mathrm{I}_{2}$.

Table (4-a): Thousand grain weight (gm) as affected by the interaction between Irrigation levels (I) and Varieties (V) ( combined data)

\begin{tabular}{|c|c|c|c|}
\hline \multirow{2}{*}{ Verities(V) } & \multicolumn{3}{|c|}{ Irrigation Levels(I) } \\
\cline { 2 - 4 } Sakha 93 & FC 100\% & FC 80\% & FC 60\% \\
\cline { 2 - 4 } & $\mathrm{A}$ & $\mathrm{B}$ & $\mathrm{C}$ \\
\hline \multirow{2}{*}{ Giza 168 } & $47.54 \mathrm{a}$ & $45.47 \mathrm{~b}$ & $43.97 \mathrm{~b}$ \\
\hline \multirow{2}{*}{ Gimmeiza 9 } & $46.19 \mathrm{a}$ & $44.51 \mathrm{~b}$ & $\mathrm{C}$ \\
\cline { 2 - 4 } & $\mathrm{A}$ & $\mathrm{AB}$ & $\mathrm{B}$ \\
\cline { 2 - 4 } & $47.30 \mathrm{a}$ & $46.70 \mathrm{a}$ & $45.65 \mathrm{a}$ \\
\hline
\end{tabular}


J. Agric. Sci. Mansoura Univ., 33 (7), July, 2008

F4-5-6 
Data given in Table (4-b) and graphically illustrated in Fig. (5) cleared that 1000 -grain weight in the combined analysis was significantly affected by the interaction between irrigation levels and seeding rates . Results showed that 1000 -grain weight was significantly increased with increasing irrigation levels up to irrigation level $l_{1}(100 \%$ of field capacity) under different seeding rates. Plants sown at $80 \mathrm{Kg}$. /feddan and irrigated at level $\mathrm{I}_{1}(80 \%$ of field capacity) produced highest 1000-grain weight. While the lowest ones was found under Irrigation levels $\mathrm{I}_{3}(60 \%$ of field capacity) at different seeding rates.

Table (4-b): Thousand grain weight (gm) as affected by the interaction between Irrigation levels (I) and seeding rates (S) (combined data)

\begin{tabular}{|c|c|c|c|}
\hline \multirow[b]{2}{*}{ Seeding rates(S) } & \multicolumn{3}{|c|}{ Irrigation Levels(I) } \\
\hline & FC $100 \%$ & FC $80 \%$ & FC $60 \%$ \\
\hline & A & A & B \\
\hline $60 \mathrm{Kg} . / \mathrm{fed}$ & $48.70 \mathrm{a}$ & $47.23 \mathrm{a}$ & $42.37 \mathrm{a}$ \\
\hline $70 \mathrm{Ka} / \mathrm{fed}$. & $\frac{A}{46.74 b}$ & $\frac{A}{46.45 a}$ & $\frac{B}{4385 a}$ \\
\hline $80 \mathrm{~kg} . / \mathrm{fed}$. & $\frac{A}{45.59 \mathrm{~b}}$ & $\frac{B}{43.00 b}$ & $\begin{array}{c}\mathrm{C} \\
41.76 \mathrm{a}\end{array}$ \\
\hline
\end{tabular}

Results in Table (4-c) and graphically illustrated in Fig. (6) Showed that 1000 -grain weight in the combined analysis was significantly affected by the interaction between varieties and seeding rates. Data revealed that 1000 grain weight for the three cultivars tested was significantly decreased with increasing seeding rates. Gimmeiza9 gave heaviest grain weight $(47.63 \mathrm{gm})$ at seeding rate $60 \mathrm{Kg}$./fed. While Giza 168 gave the lowest one (41.00) at seeding rate $80 \mathrm{Kg}$./feddan.

Table (4-c): Thousand grain weight (gm) as affected by the interaction between Varieties (V) and seeding rates (S) ( combined data)

\begin{tabular}{|c|c|c|c|}
\hline \multirow{2}{*}{ Seeding rates(S) } & \multicolumn{3}{|c|}{ Varieties (V) } \\
\cline { 2 - 4 } & Sakha 93 & Giza 168 & Gimmeiza 9 \\
\cline { 2 - 4 } $\mathbf{6 0} \mathbf{~ K g . / f e d ~}$ & $\mathrm{A}$ & $\mathrm{B}$ & $\mathrm{A}$ \\
\hline \multirow{2}{*}{$\mathbf{7 0} \mathbf{~ K g . / f e d . ~}$} & $\mathrm{A}$ & $44.23 \mathrm{a}$ & $47.63 \mathrm{a}$ \\
\cline { 2 - 4 } & $46.04 \mathrm{a}$ & $43.83 \mathrm{a}$ & $\mathrm{A}$ \\
\hline \multirow{2}{*}{$\mathbf{8 0} \mathbf{~ k g . / f e d .}$} & $\mathrm{A}$ & $\mathrm{B}$ & $47.17 \mathrm{a}$ \\
\cline { 2 - 4 } & $44.50 \mathrm{~b}$ & $41,00 \mathrm{~b}$ & $\mathrm{~A}$ \\
\hline
\end{tabular}

\section{D.3. Grain yield (ardab/feddan):}

Results in Table (4-d) and graphically illustrated in Fig. (7) Showed that grain yield (ardab/feddan) of wheat in the combined analysis was significantly affected by the interaction between irrigation levels and varieties. Results showed that grain yield (ardab/feddan) for each of Gimmeiza 9 and Sakha 93 surpassed Giza 168 cultivar at different irrigation levels. Grain yield of wheat (ardab/feddan) significantly increased with increasing of irrigation levels up to $I_{1}(100 \%$ of field capacity) for Sakha 93 cultivar (22.22 
ardab/feddan) for Gimmeiza 9 (22.88 ardab/feddan) and Giza 168 (20.56 ardab/feddan).

Table (4-d): Grain yield (ardab/fed.) as affected by the interaction between Irrigation levels (I) and Varieties (V) ( combined data)

\begin{tabular}{|c|c|c|c|}
\hline \multirow[b]{2}{*}{ Varities(V) } & \multicolumn{3}{|c|}{ Irrigation Levels(I) } \\
\hline & FC $100 \%$ & FC $80 \%$ & FC $60 \%$ \\
\hline \multirow[b]{2}{*}{ Sakha 93} & $A$ & $B$ & $B$ \\
\hline & $22.22 \mathrm{a}$ & $20.74 \mathrm{ab}$ & $19.38 \mathrm{a}$ \\
\hline \multirow[b]{2}{*}{ Giza 168} & A & A & $\mathrm{B}$ \\
\hline & $20.56 \mathrm{~b}$ & $19.36 \mathrm{~b}$ & $17.59 \mathrm{~b}$ \\
\hline \multirow[b]{2}{*}{ Gimmeiza 9} & $A$ & $A$ & $B$ \\
\hline & $22.83 \mathrm{a}$ & $21.52 \mathrm{a}$ & $19.97 \mathrm{a}$ \\
\hline
\end{tabular}

Data given in Table (4-e) and graphically illustrated in Fig. (8) showed that grain yield (ardab/feddan) in the combined analysis was significantly affected by the interaction between irrigation levels and seeding rates .Data showed that grain yield (ardab/feddan) was significantly increased with increasing irrigation levels up to irrigation level $I_{1}(100 \%$ of field capacity) under different seeding rates. The highest grain yield of wheat (22.95 ardab/feddan) was obtained when wheat plants sown at $80 \mathrm{Kg}$./feddan and irrigated at level $l_{1}(100 \%$ of field capacity $)$.

Table (4-e): Grain yield (ardab/fed.) as affected by the interaction between Irrigation levels (I) and seeding rates (S) (combined data)

\begin{tabular}{|c|c|c|c|}
\hline \multirow{2}{*}{ Seeding rates(S) } & \multicolumn{3}{|c|}{ Irrigation Levels(I) } \\
\cline { 2 - 4 } & FC 100\% & FC 80\% & FC 60\% \\
\cline { 2 - 4 } $\mathbf{6 0} \mathbf{~ K g . / f e d ~}$ & $\mathrm{A}$ & $\mathrm{AB}$ & $\mathrm{B}$ \\
\hline \multirow{3}{*}{$\mathbf{7 0} \mathbf{~ K g . / f e d . ~}$} & $\mathrm{A}$ & $19.22 \mathrm{~b}$ & $17.79 \mathrm{~b}$ \\
\cline { 2 - 4 } & $21.83 \mathrm{ab}$ & $20.19 \mathrm{~b}$ & $\mathrm{~B}$ \\
\hline \multirow{2}{*}{$\mathbf{8 0} \mathbf{~ k g . / f e d . ~}$} & $\mathrm{A}$ & $\mathrm{A}$ & $\mathrm{B}$ \\
\cline { 2 - 4 } & $22.95 \mathrm{a}$ & $22.21 \mathrm{a}$ & $20.30 \mathrm{a}$ \\
\hline
\end{tabular}

Results in Table (4-f) and graphically illustrated in Fig. (9) showed that grain yield of wheat in the combined analysis was significantly affected by the interaction between varieties and seeding rates. Data cleared that grain yield of Gimmeiza9 cultivar increased significantly with increasing seeding rates up to $80 \mathrm{Kg}$./feddan, while grain yield/feddan increased significantly up to seeding rate $70 \mathrm{Kg}$./feddan for Sakha 93 and Giza 168. Under seeding rate $60 \mathrm{Kg}$./feddan Giza 168 cultivar produced lowest grain yield (18.42 ardab/feddan), however Sakha 93 gave highest yield (21.20 ardab/feddan) under seeding rate $70 \mathrm{Kg}$./feddan ,while Gimmeiza 9 cultivar gave highest grain yield ( $23.48 \mathrm{ardab} / \mathrm{feddan})$ at seeding rate $80 \mathrm{Kg} . / \mathrm{fed}$. 
Ramadan, A.R. and S. S. Awaad

F7-8-9

4732 
Table (4-f): Grain yield (ardab/fed.) as affected by the interaction between Varieties (V) and seeding rates (S) (combined data)

\begin{tabular}{|c|c|c|c|}
\hline \multirow{2}{*}{ Seeding rates(S) } & \multicolumn{3}{|c|}{ Varieties (V) } \\
\cline { 2 - 4 } & Sakha 93 & Giza 168 & Gimmeiza 9 \\
\hline \multirow{2}{*}{$\mathbf{6 0} \mathbf{~ K g . / f e d ~}$} & $\mathrm{A} \mathrm{B}$ & $\mathrm{B}$ & $\mathrm{A}$ \\
\cline { 2 - 4 } & $19.25 \mathrm{~b}$ & $18.42 \mathrm{~b}$ & $20.17 \mathrm{~b}$ \\
\hline \multirow{2}{*}{$\mathbf{7 0} \mathbf{~ K g . / f e d . ~}$} & $\mathrm{A}$ & $\mathrm{B}$ & $\mathrm{A}$ \\
\hline \multirow{2}{*}{$\mathbf{8 0} \mathbf{~ k g . / f e d .}$} & $21.20 \mathrm{ab}$ & $19.00 \mathrm{ab}$ & $20.67 \mathrm{~b}$ \\
\cline { 2 - 4 } & $\mathrm{B}$ & $\mathrm{B}$ & $\mathrm{A}$ \\
\hline
\end{tabular}

\section{E- Correlation analysis:}

The results in table (5) clearly indicated that grain yield /feddan appeared to be positively and significantly correlated with plant height and number of spikes $/ \mathrm{m}^{2}$. However, positive and insignificant relationship was obtained with each of spike length, number of spikelets/spike, number of grains/spike and spike grain weight, 1000-grain weight and straw yield/feddan. Thus, it seems evident that all the abovementioned characters contributed to grain yield of wheat. in this respect. El- Banna and Aly (1993), Tammam et al (2000), Kamboj et al (2000) and Ramadan (2003) showed that significant and positive association of different attributes with grain yield/feddan indicating the importance of different characters, viz number of spikes $/ \mathrm{m}^{2}$, number of grains/spike and 1000 - grain weight.

Plant height was positivly and highly significantly correlated with number of spikes $/ \mathrm{m}^{2}$ and straw yield/feddan. However, that correlation with the rest characters was negative and insignificant.

Table (5): Correlation coefficient between grain yield and some yield attributes of wheat (Combined) data)

\begin{tabular}{|c|c|c|c|c|c|c|c|c|}
\hline & 1 & 2 & 3 & 4 & 5 & 6 & 7 & 8 \\
\hline $\begin{array}{|ll|}\text { Grain } & \text { yield } \\
\text { (ardabffed.) }\end{array}$ & $0.598919^{\star}$ & 0.21227 & 0.448344 & 0.268315 & 0.539816 & $0.679488^{\star}$ & 0.457077 & 0.331902 \\
\hline 1-Pantheight (cm) & & -0.370476 & -0.33863 & -0.297491 & -0.092406 & $0.877098^{* *}$ & -0.252586 & $0.839813^{* *}$ \\
\hline \begin{tabular}{|l|} 
2-Spike Length \\
$(\mathrm{cm})$
\end{tabular} & & & $0.847334^{\star *}$ & $0.987504^{\star *}$ & $0.9157187^{* *}$ & -0.41071 & $0.936422^{\star *}$ & -0.156756 \\
\hline \begin{tabular}{|cc}
- & No. of \\
spikelets/spike
\end{tabular} & & & & $0.820589 * *$ & $0.863311^{\star \star}$ & -0.13939 & $0.910854^{* *}$ & -0.269809 \\
\hline $4-\underset{\text { grains/spike }}{\text { No. of }}$ & & & & & $0.950292^{\star \star}$ & -0.37434 & $0.932908^{\star \star}$ & -0.10761 \\
\hline 5- $\begin{array}{c}\text { Spike grain } \\
\text { weight(gm) }\end{array}$ & & & & & & -0.12592 & $0.944387^{\star \star}$ & -0.00403 \\
\hline 6-No. of spikes/m2 & & & & & & & -0.213021 & $0.625998^{*}$ \\
\hline $\begin{array}{c}\text { 7-Thousand grain } \\
\text { weight(gm) }\end{array}$ & & & & & & & & -0.195894 \\
\hline 8-Strawyieldfed. & & & & & & & & \\
\hline $\begin{array}{l}\text { Grain yield (ar } \\
\text { Grain yield (ar } \\
\text { Grain yield (ar }\end{array}$ & dab/fed. & $x$ No. & & ke & & $\begin{array}{l}=0.8243 \\
=0.6761 \\
=0.5180\end{array}$ & & \\
\hline
\end{tabular}


Ramadan, A.R. and S. S. Awaad 
Spike length show positive and highly significant correlated with number of spikelets/spike, number of grains/spike, spike grain weight and 1000 -grain weight. However, that correlation with number of spikes $/ \mathrm{m}^{2}$ and straw yield/feddan was negative and insignificant.

Number of spikelets/spike revealed that positive and highly significant correlated with number of grains /spike, spike grain weight and 1000-grain weight. However, that correlation with number of spikes $/ \mathrm{m}^{2}$ and straw yield/feddan was negative and insignificant

Number of grains/spike showed that positive and highly significant correlated with spike grain weight and 1000-grain weight. However, that correlation with number of spikes $/ \mathrm{m}^{2}$ and straw yield/feddan was negative and insignificant

Spike grain weight cleared that positive and highly significant correlated with 1000-grain weight. However that correlation with number of spikes $/ \mathrm{m}^{2}$ and straw yield/feddan was negative and insignificant.

Number of spikes $/ \mathrm{m}^{2}$ showed that positive and significant correlated with straw yield/feddan. However, that correlation with 1000-grain weight was negative and insignificant

Thousand grain weights showed that negative and insignificant correlated with straw yield /feddan. Similar results were found by Bassiouny (1985), El- Banna and Aly (1993), Ramadan (2003)

\section{REFERENCES}

Abdalla, M. M. and A. H. Bassiouny (1994): Response of two released wheat cultivars to various planting densities. Egypt J. Appl. Sci., 9 (8): 836 849.

Abd El-Gawad; K. A. El-Shouny; S. A. Saleh and M. A. Ahmed (1987): Partition of nitrogen of dry matter in newly cultivated wheat varieties. Egypt, J. Agron. 12. (1-2):1-16.

Abo-Warda, A. M. A. (1997): Productivity of some wheat cultivars and lines in sandy soil. Egypt J. Appl. Sci. (12) : 86-90.

Aly, M. H. , M. R. Hoque , A. A. Hassan and A. Khair (2007): Effects of deficit irrigation on yield, water productivity, and economic returns of wheat. Agricultural Water Management 92 (3) : 151-161.

Al-Kaisi, M.M., Berrada, A. and Stack, M. (1997): Evaluation of irrigation scheduling program and spring wheat yield response in southwestern Colorado. Agricultural Water Management 34: 137-148.

Bassal, S. A. A. (1997): Effect of preceding summer crop and population densities on the productivity of wheat under different potassium fertilizer levels. J. Agric., Sci. Mansoura Univ., 22 (9): 2789-2797.

Bassiouny, A. H. M. (1985): Studies on yield potentiAlyty in wheat. Ph.D. Thesis, Fac. Agric. Zagazig Univ., Egypt.

Blum, A. and Y. Punel (1990): Physiological attributes associated with drought resistance of wheat cultivars in Mediterranean environment. Asut, J. Agric. Res. 41: 799-810.

Darwish, A. A. (1994): Agricultural studies on wheat. Ph.D. Thesis. Fac. Agric., Zagazig Univ., Egypt.

Duncan, B. D. (1955): Multiple ranges and multiple F.Test Biometrics, 11:142 . 
El-Banna, A.Y. A. (1999): Response of wheat varieties to planting density and nitrogen fertilization under newly cultivated soil conditions. M.Sc. Thesis, Fac. of Agric., Zagazig Uni., Egypt.

El-Banna, A.Y.A. (2000): Effect of seeding rates and PK fertilizer levels on grain yield and yield attributes of wheat under newly cultivated sandy soil conditions. Zagazig J.Agric.Res., 27 (5): 1161-1178.

El-Banna, A.Y. A. and H.A. Basha (1994): Response of yield and yield attributes of wheat (Triticum aestivum L.) to planting density under newly cultivated sandy soil. Zagazig J. Agric. Res., 21 (3A): 671-681.

El-Banna, A. Y. A. and R. M. Aly (1993): Effect of nitrogen fertilization levels on yield and yield attributes of some wheat cultivars (Triticum aestivum L.) in newly cultivated sandy soil. Zagazig J. Agric. Res., 20: 18391849.

El-Karamity, A.E. (1998): Response of some wheat cultivars to seeding rate and $\mathrm{N}$ fertilization rates J. Agric. Mansoura Univ., 23 (2); 643-655.

English, M.J. and Nakamura, B. (1989): Effects of deficit irrigation and irrigation frequency on wheat yields. Journal of Irrigation and Drainage Engineering, ASCE 115: 172-184.

Fisher, R. A. (1960): The design of experiments $8^{\text {th }}$ Edition Oliver and Boyed Edinburgh.

Ghahraman, B. and Sepaskhah, A.R. (1997): Use of a water deficit sensitivity index for partial irrigation scheduling of wheat and barley. Irrigation Science 18:11-16

Husman, S. H.; M. J. Ottman, R. J. Wegener and M. T. Rogers (2000): Durum wheat response to soil water depletion levels. Arizona Grain Research and Promotion Council. http://ag.arizona. edu/pubs/ crops/az1185/

Hussein, S.M.A. (2005): Effect of supplemental irrigations, seeding rates and foliar application of potassium macro-micro elements on wheat productivity under rainfed conditions. Bulletin of Faculty of Agriculture, Cairo University. 56 (3): 431-453.

Kamboj, M. C., Subhadra; Naveen Chandra and R.K. Yadava (2000): Relationship between quality traits and grain yield in bread wheat (Triticum aestivum L). Annals of Agric Bio Research 5 (1): 87-89.

Khater. A. N.; H.H. Abdel-Maksoud and H. M Eid (1997): Response of some wheat cultivares and their water relations to different irrigation levels in Middle Delta. Egypt J. Appl. Sci. 12 (5) 142-158.

Kramer, P. J. and Boyer, J.S. (1995): Water relationship of plants and soils. San Diego: Academic Press. 495P.

Mahmoud, S. K. (1988): Study on some agriculture factors affecting growth, yield, yield attributes and technological characteristics of wheat. Ph.D. Thesis, Fac. Of Agric., Minia Univ., Egypt.

Mosaad, M. G., G. Ortiz-Ferrara and V. Mahalak-Shmi (1995): Tiller development and contribution to yield under different moisture regimes in two Triticum species. J. Agron. And crop Sci., 17: 173-180.

Ouda, S.A. (2006): Precicting the effect of water and salinity stresses on wheat yield and water needs. J. Appl. Sci. Res., 2 (10): 750-756.

Ramadan, A. R. (2003): Breeding for improvement wheat plant characteristics. Ph.D Thesis, Fac. Agric., Zagazig Univ., Egypt.

Saini, H. S., M. Sedgley and D. A. spinall, (1984): Developmental anatomy in wheat of male sterility induced by heat stress. Water deficit or abscisic acid. Aust. J. Plant physiol., 11:243-254. 
Salem, A. H., H. A. Rabie, M. A. Mohamed and M.S. Salem (1990): Association between grain yield and its contributing characters in some wheat genotypes as influenced by locations and seeding rates. Proc. $4^{\text {th }}$ Conf. Agron., Cairo, 1: 89-97.

Sendecor G. W. and W. G. Cochran (1967). Statistatical methods, $7^{\text {th }}$ ed. Lowa stat Univ. press. Ames. Lowa, USA.

Tammam, A. A., S. A. Aly and E. A. M. El- Sayed (2000): Phenotypic, genotypic correlations and path coefficient analysis in bread wheat crosses. Assiut. J. of agric. Sci. 31: 73-85.

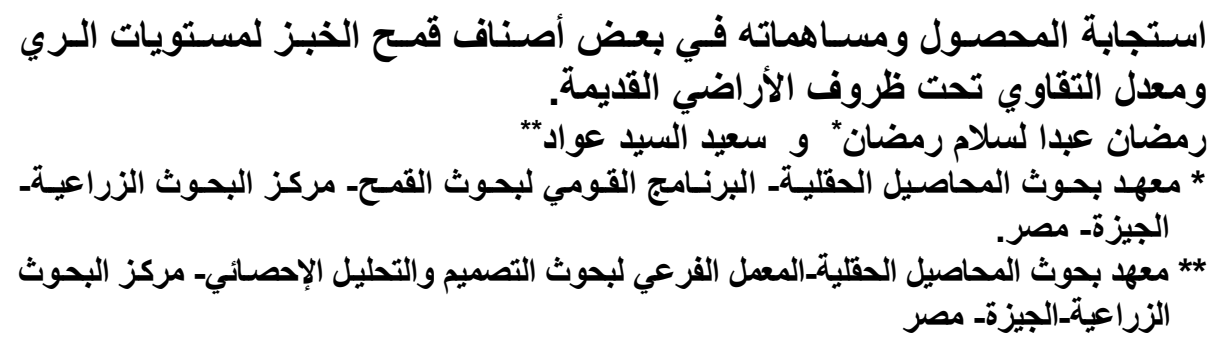

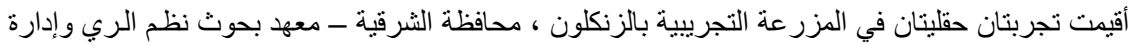

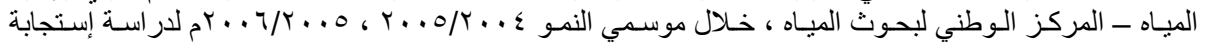

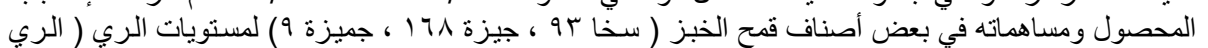

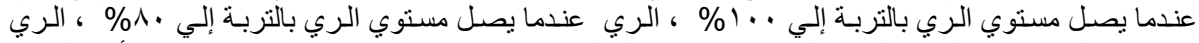

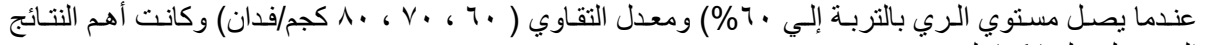

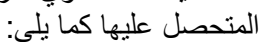

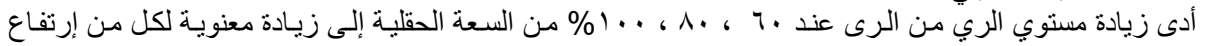

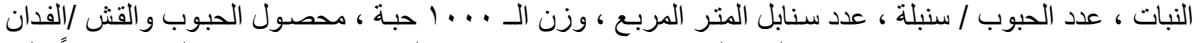

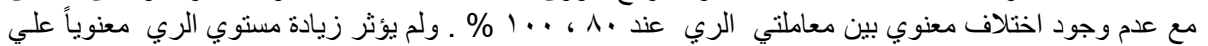

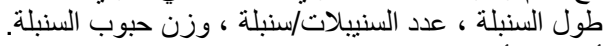

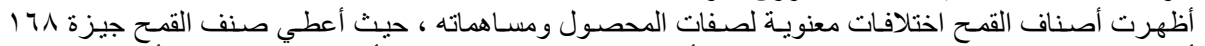

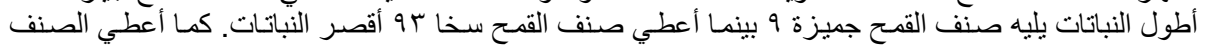

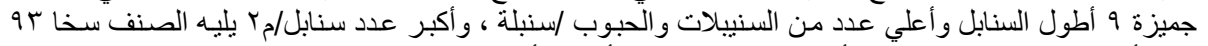

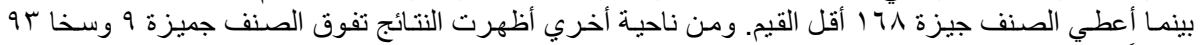

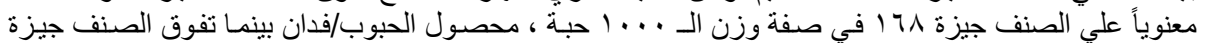

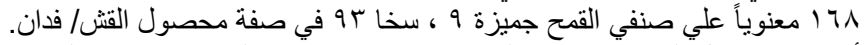

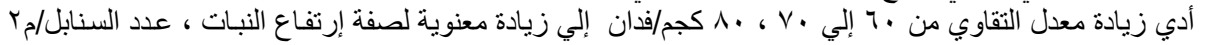

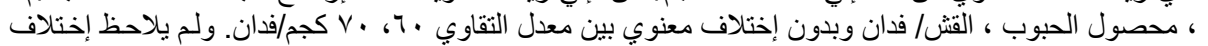

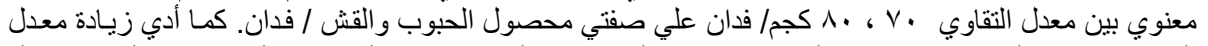

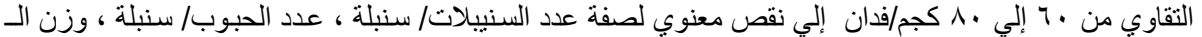

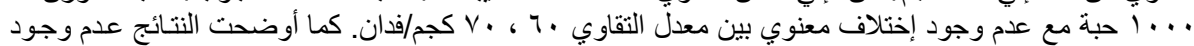

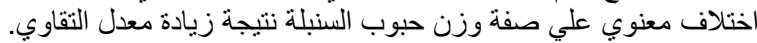

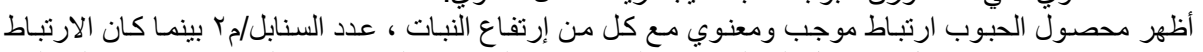

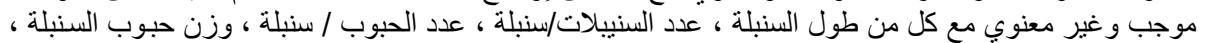

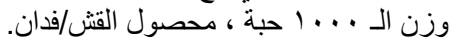

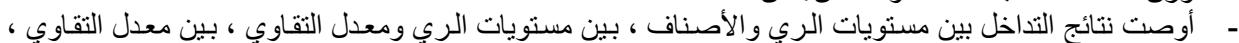

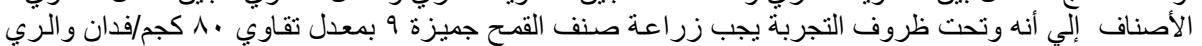

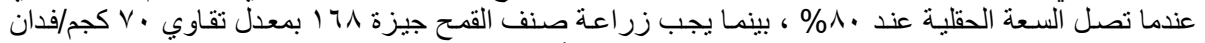

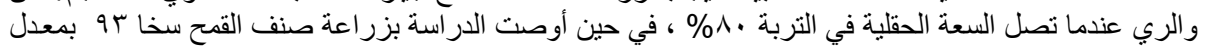

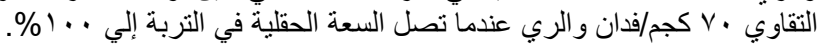


Table (2): Effect of irrigation levels, varieties and seeding rates on plant height "cm" Spike length "cm" and No. of spikelet's/spike of wheat in the 1st and 2 nd seasons and the combined.

\begin{tabular}{|c|c|c|c|c|c|c|c|c|c|}
\hline \multirow[b]{2}{*}{ Main effects and interaction } & \multicolumn{3}{|c|}{ Plant height "cm" } & \multicolumn{3}{|c|}{ Spike length "cm" } & \multicolumn{3}{|c|}{ No. of spikelets/spike } \\
\hline & $\begin{array}{c}\text { 1st } \\
\text { season }\end{array}$ & $\begin{array}{c}\text { 2nd } \\
\text { season }\end{array}$ & combined & $\begin{array}{c}1 \text { st } \\
\text { season }\end{array}$ & $\begin{array}{c}\text { 2nd } \\
\text { season }\end{array}$ & combined & $\begin{array}{c}\text { 1st } \\
\text { season }\end{array}$ & $\begin{array}{c}\text { 2nd } \\
\text { season }\end{array}$ & combined \\
\hline \multicolumn{10}{|l|}{ Irrigation levels (I): } \\
\hline $100 \%$ of Field Capacity (I1) & $93.44 \mathrm{a}$ & $103.84 \mathrm{a}$ & $98.64 \mathrm{a}$ & 9.10 & 10.02 & 9.56 & 16.58 & $22.06 \mathrm{a}$ & 19.32 \\
\hline $80 \%$ of Field Capacity (I2) & $92.95 \mathrm{a}$ & $102.55 \mathrm{a}$ & $97.75 \mathrm{a}$ & 8.33 & 9.11 & 8.72 & 15.86 & $21.06 a b$ & 18.46 \\
\hline $60 \%$ of Field Capacity (I3) & 90.45 & $97.15 \mathrm{~b}$ & $93.8 \mathrm{~b}$ & 7.91 & 8.55 & 8.23 & 15.59 & $20.63 \mathrm{~b}$ & 18.11 \\
\hline F.Test & * & * & * & n.s & n.s & n.s & $\mathrm{ns}$ & * & n.s \\
\hline \multicolumn{10}{|l|}{ Varieties (V): } \\
\hline Sakha 93 (V1) & $89.62 \mathrm{~b}$ & $99.22 \mathrm{~b}$ & $94.42 \mathrm{~b}$ & 8.6 & 9.18 & 8.89 & 15.75 & $21.71 \mathrm{a}$ & $18.73 \mathrm{ab}$ \\
\hline Giza 168 (V2) & $94.07 \mathrm{a}$ & $103.69 \mathrm{a}$ & $98.88 \mathrm{a}$ & 8.12 & 8.68 & 8.40 & 15.66 & $19.56 \mathrm{~b}$ & $17.61 \mathrm{~b}$ \\
\hline Gimmeiza 9 (V3) & $93.15 \mathrm{a}$ & 100.63ab & $96.89 \mathrm{a}$ & 8.62 & 9.82 & 9.22 & 16.62 & $22.48 \mathrm{a}$ & $19.55 \mathrm{a}$ \\
\hline F.Test & * & * & * & ns & n.s & n.s & n.s & * & * \\
\hline \multicolumn{10}{|l|}{ Seeding rates (S): } \\
\hline $60 \mathrm{Kg} . / \mathrm{feddan}(\mathrm{S} 1)$ & $86.98 \mathrm{c}$ & $95.86 \mathrm{c}$ & $91.42 \mathrm{c}$ & 9.08 & 9.72 & 9.40 & $17.32 \mathrm{a}$ & $22.96 \mathrm{a}$ & $20.14 a$ \\
\hline $70 \mathrm{Kg} . /$ feddan (S2) & $92.66 \mathrm{~b}$ & $101.60 \mathrm{~b}$ & $97.13 \mathrm{~b}$ & 8.80 & 9.40 & 9.10 & $15.15 b$ & $21.81 \mathrm{a}$ & $18.48 \mathrm{~b}$ \\
\hline $80 \mathrm{Kg} . /$ feddan (S3) & $97.20 \mathrm{a}$ & $106.08 \mathrm{a}$ & $101.64 \mathrm{a}$ & 7.46 & 8.56 & 8.01 & $15.56 \mathrm{~b}$ & $18.98 \mathrm{~b}$ & $17.27 \mathrm{~b}$ \\
\hline F.Test & ** & ** & ** & n.s & n.s & n.s & * & ** & ** \\
\hline \multicolumn{10}{|l|}{ Interactions: } \\
\hline $\mathrm{xV}$ & n.s & n.s & n.s & n.s & * & n.s & n.s & * & * \\
\hline$x S$ & n.s & n.s & n.s & 立 & n.s & ** & ** & n.s & * \\
\hline$V \times S$ & $\star *$ & * & $\star \star$ & ** & * & ** & * & $\star *$ & $\star \star$ \\
\hline $1 \times V \times S$ & ** & $\star \star$ & ** & ** & ** & ** & ** & * & $\star \star$ \\
\hline
\end{tabular}


Table (3): Effect of irrigation levels, varieties and seeding rates on No. of grains/spike , spike grain weight (gm) and No. spikes $/ \mathrm{m}^{2}$ of wheat in the $1^{\text {st }}$ and $2^{\text {nd }}$ seasons and the combined.

\begin{tabular}{|c|c|c|c|c|c|c|c|c|c|}
\hline \multirow[b]{2}{*}{ Main effects and interaction } & \multicolumn{3}{|c|}{ No. of grains/spike } & \multicolumn{3}{|c|}{ Spike grain weight (gm) } & \multicolumn{3}{|c|}{ No. of spike $/ \mathrm{m}^{2}$} \\
\hline & $\begin{array}{c}1^{\text {st }} \\
\text { season }\end{array}$ & $\begin{array}{c}\text { 2nd } \\
\text { season }\end{array}$ & combined & $\begin{array}{c}1^{\text {st }} \\
\text { season }\end{array}$ & $\begin{array}{c}2^{\text {nd }} \\
\text { season }\end{array}$ & combined & $\begin{array}{c}1^{\mathrm{St}} \\
\text { season }\end{array}$ & $\begin{array}{c}2^{\text {nd }} \\
\text { season }\end{array}$ & combined \\
\hline \multicolumn{10}{|l|}{ Irrigation levels (I): } \\
\hline $100 \%$ of Field Capacity (I1) & $51.54 \mathrm{a}$ & $62.40 \mathrm{a}$ & $56.97 \mathrm{a}$ & 2.41 & $2.95 \mathrm{a}$ & $2.68 \mathrm{a}$ & $394.35 \mathrm{a}$ & $439.87 \mathrm{a}$ & $417.11 \mathrm{a}$ \\
\hline $80 \%$ of Field Capacity (12) & $51.11 \mathrm{a}$ & $60.11 \mathrm{ab}$ & $55.61 \mathrm{a}$ & 2.26 & $2.82 \mathrm{a}$ & $2.54 \mathrm{ab}$ & $392.90 \mathrm{a}$. & $433.76 \mathrm{a}$ & $413.33 \mathrm{a}$ \\
\hline $60 \%$ of Field Capacity (I3) & $49.00 \mathrm{~b}$ & $58.86 \mathrm{~b}$ & $53.93 \mathrm{~b}$ & 2.10 & $2.50 \mathrm{~b}$ & $2.30 \mathrm{~b}$ & $387.29 \mathrm{~b}$ & $422.49 \mathrm{~b}$ & $404.89 \mathrm{~b}$ \\
\hline F.Test & * & ** & * & ns & * & * & ** & ** & * \\
\hline \multicolumn{10}{|l|}{ Varieties (V): } \\
\hline Sakha 93 (V1) & 51.07 & 60.33 & 55.70 & 2.34 & 2.74 & $2.54 \mathrm{a}$ & $377.79 \mathrm{c}$ & $414.65 \mathrm{c}$ & $396.22 \mathrm{c}$ \\
\hline Giza 168 (V2) & 49.29 & 59.87 & 54.58 & 2.08 & 2.66 & $2.37 \mathrm{~b}$ & $390.81 \mathrm{~b}$ & $431.85 \mathrm{~b}$ & $411.33 \mathrm{~b}$ \\
\hline Gimmeiza 9 (V3) & 51.29 & 61.17 & 56.23 & 2.35 & 2.87 & $2.61 \mathrm{a}$ & $405.94 \mathrm{a}$ & $449.62 \mathrm{a}$ & $427.78 \mathrm{a}$ \\
\hline F.Test & ns & n.s & ns & n.s & ns & ${ }^{*}$ & ** & ** & ** \\
\hline \multicolumn{10}{|l|}{ Seeding rates (S): } \\
\hline $60 \mathrm{Kg} . / \mathrm{feddan}(\mathrm{S} 1)$ & 51.31 & 61.79 & $56.55 \mathrm{a}$ & 2.33 & 2.83 & 2.58 & $366.31 \mathrm{c}$ & $399.69 \mathrm{c}$ & $383.00 \mathrm{c}$ \\
\hline $70 \mathrm{Kg} . / \mathrm{feddan}(\mathrm{S} 2)$ & 51.13 & 61.13 & $56.13 \mathrm{a}$ & 2.30 & 2.79 & 2.54 & $383.96 \mathrm{~b}$ & $430.92 \mathrm{~b}$ & $407.44 \mathrm{~b}$ \\
\hline $80 \mathrm{Kg} . / \mathrm{feddan}$ (S3) & 49.21 & 58.45 & $53.83 \mathrm{~b}$ & 2.14 & 2.66 & 2.40 & $424.27 \mathrm{a}$ & $465.51 \mathrm{a}$ & $444.89 \mathrm{a}$ \\
\hline F.Test & ns & n.s & * & ns & ns & ns & ** & ** & ** \\
\hline \multicolumn{10}{|l|}{ Interactions: } \\
\hline $1 \times V$ & ** & * & * & * & * & ns & * & * & * \\
\hline$\times 5$ & * & ** & ** & * & ** & * & ** & ** & * \\
\hline$V \times S$ & ** & * & ** & ** & * & * & * & $\star \star \star *$ & ** \\
\hline $1 \times V \times S$ & ** & ** & ** & ** & ** & ** & ** & * & ** \\
\hline
\end{tabular}




\section{Ramadan, A.R. and S. S. Awaad}

Table (4): Effect of irrigation levels, varieties and seeding rates on Thousand grain weight "gm" Grain yield (ardab /fed and Straw yield" ton/fed.) of wheat in the $1^{\text {st }}$ and $2^{\text {nd }}$ seasons and the combined

\begin{tabular}{|c|c|c|c|c|c|c|c|c|c|}
\hline \multirow{3}{*}{$\begin{array}{l}\text { Main effects and interaction } \\
\text { Irrigation levels (I): }\end{array}$} & \multicolumn{3}{|c|}{ Thousand grain weight "gm" } & \multicolumn{3}{|c|}{ Grain yield "ardab/fed." } & \multicolumn{3}{|c|}{ Straw yield" } \\
\hline & \multirow[t]{2}{*}{$\begin{array}{c}1^{\text {st }} \\
\text { season }\end{array}$} & \multirow[t]{2}{*}{$\begin{array}{c}2^{\text {nd }} \\
\text { season }\end{array}$} & combined & \multirow[t]{2}{*}{$\begin{array}{c}1^{\text {st }} \\
\text { season }\end{array}$} & \multirow[t]{2}{*}{$\begin{array}{c}2^{\text {nd }} \\
\text { season }\end{array}$} & \multirow[t]{2}{*}{ combined } & \multirow[t]{2}{*}{$\begin{array}{c}1^{\text {st }} \\
\text { season }\end{array}$} & \multirow[t]{2}{*}{$\begin{array}{c}2^{\text {nd }} \\
\text { season }\end{array}$} & \multirow[t]{2}{*}{ combined } \\
\hline & & & & & & & & & \\
\hline $100 \%$ of Field Capacity (I1) & $46.75 \mathrm{a}$ & $47.27 \mathrm{a}$ & $47.01 \mathrm{a}$ & $20.19 \mathrm{a}$ & $23.55 \mathrm{a}$ & $21.87 \mathrm{a}$ & $12.24 \mathrm{a}$ & $13.06 \mathrm{a}$ & $12.65 \mathrm{a}$ \\
\hline $80 \%$ of Field Capacity (I2) & $44.21 \mathrm{ab}$ & $46.91 \mathrm{a}$ & $45.56 \mathrm{a}$ & $19.54 \mathrm{ab}$ & $21.54 \mathrm{ab}$ & $20.54 \mathrm{ab}$ & $11.68 \mathrm{a}$ & $12.18 \mathrm{ab}$ & $11.93 \mathrm{a}$ \\
\hline $60 \%$ of Field Capacity (I3) & $42.85 \mathrm{~b}$ & $42.47 \mathrm{~b}$ & $42.66 \mathrm{~b}$ & $18.59 \mathrm{~b}$ & $19.37 \mathrm{~b}$ & $18.98 \mathrm{~b}$ & $9.27 \mathrm{~b}$ & $11.29 \mathrm{~b}$ & $10.28 \mathrm{~b}$ \\
\hline F.Test & * & * & $* *$ & $* *$ & $* *$ & $* *$ & $* *$ & $* *$ & $* *$ \\
\hline \multicolumn{10}{|l|}{ Varieties (V): } \\
\hline Sakha 93 (V1) & $45.81 \mathrm{a}$ & $45.51 \mathrm{~b}$ & $45.66 \mathrm{a}$ & $19.65 \mathrm{ab}$ & $21.91 \mathrm{ab}$ & $20.78 \mathrm{ab}$ & $10.06 \mathrm{~b}$ & $10.10 \mathrm{~b}$ & $10.08 \mathrm{c}$ \\
\hline Giza 168 (V2) & $42.19 \mathrm{~b}$ & $43.85 \mathrm{c}$ & $43.02 \mathrm{~b}$ & $18.23 \mathrm{~b}$ & $20.11 \mathrm{~b}$ & $19.17 \mathrm{~b}$ & $12.01 \mathrm{a}$ & $14.47 \mathrm{a}$ & $13.24 \mathrm{a}$ \\
\hline Gimmeiza 9 (V3) & $45.81 \mathrm{a}$ & $47.29 \mathrm{a}$ & $46.55 \mathrm{a}$ & $20.43 \mathrm{a}$ & $22.45 \mathrm{a}$ & $21.44 \mathrm{a}$ & $11.12 \mathrm{ab}$ & $11.96 \mathrm{~b}$ & $11.54 \mathrm{~b}$ \\
\hline F.Test & * & ** & ** & ** & ** & ** & *夫 & ** & ** \\
\hline \multicolumn{10}{|l|}{ Seeding rates (S): } \\
\hline $60 \mathrm{Kg} . / \mathrm{feddan}$ (S1) & $45.41 \mathrm{a}$ & $46.79 \mathrm{a}$ & $46.10 \mathrm{a}$ & $17.98 \mathrm{~b}$ & $20.58 b$ & $19.28 \mathrm{~b}$ & $9.56 \mathrm{c}$ & $11.98 \mathrm{~b}$ & $10.77 \mathrm{~b}$ \\
\hline $70 \mathrm{Kg} . / f e d d a n(S 2)$ & $44.92 \mathrm{ab}$ & $46.44 \mathrm{a}$ & $45.68 \mathrm{a}$ & $19.43 \mathrm{a}$ & $21.15 b$ & $20.29 a b$ & $11.29 \mathrm{~b}$ & $11.45 \mathrm{~b}$ & $11.37 \mathrm{ab}$ \\
\hline $80 \mathrm{Kg} . /$ feddan (S3) & $43.48 \mathrm{~b}$ & $43.42 \mathrm{~b}$ & $43.45 \mathrm{~b}$ & $20.90 \mathrm{a}$ & $22.74 \mathrm{a}$ & $21.82 \mathrm{a}$ & $12.34 \mathrm{a}$ & $13.10 \mathrm{a}$ & $12.72 \mathrm{a}$ \\
\hline F.Test & * & * & ** & ** & ** & ** & 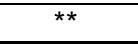 & ** & ** \\
\hline \multicolumn{10}{|l|}{ Interactions: } \\
\hline $\mathrm{V} \times \mathrm{V}$ & * & * & * & ** & $\star \star$ & ** & * & * & ** \\
\hline $\mathrm{xS}$ & * & * & * & * & $\star \star$ & * & * & * & * \\
\hline $\mathrm{V} \times \mathrm{S}$ & $\star \star$ & * & ** & $\star \star$ & * & $\star \star$ & * & ** & $\star \star$ \\
\hline $1 \times \vee \times S$ & ** & *夫 & *夫 & ** & $\star \star$ & ** & ** & ** & ** \\
\hline
\end{tabular}

